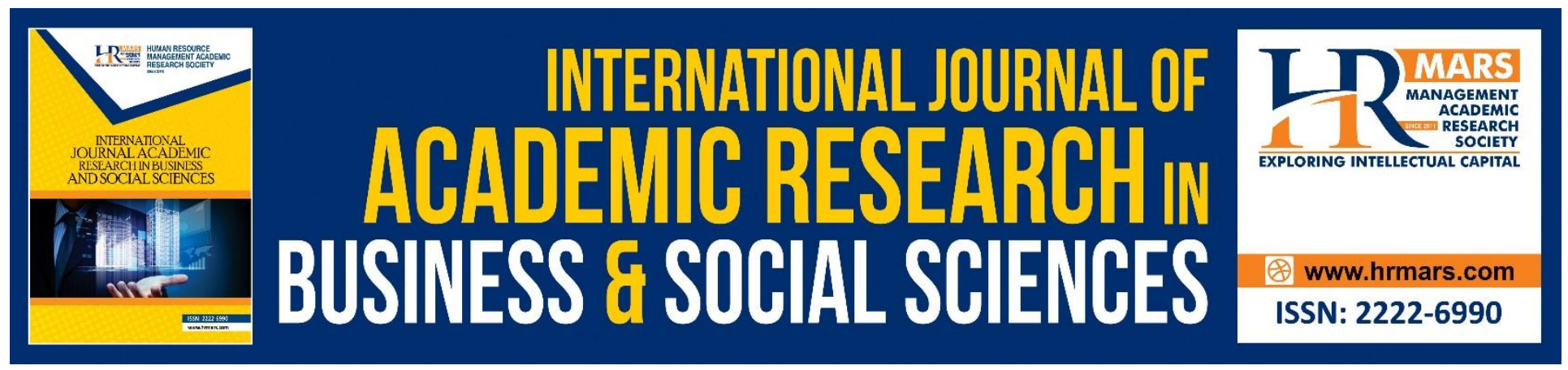

\title{
Empowering the Self-Efficacy of Teachers in Malaysia through the Academic Revolution 4.0
}

Nor Asmawati Ismail \& Najihah Abd Wahid

To Link this Article: http://dx.doi.org/10.6007/IJARBSS/v8-i11/4966

DOI: $10.6007 /$ IJARBSS/v8-i11/4966

Received: 24 Oct 2018, Revised: 22 Nov 2018, Accepted: 03 Dec 2018

Published Online: 06 Dec 2018

In-Text Citation: (Ismail \& Wahid, 2018)

To Cite this Article: Ismail, N. A., \& Wahid, N. A. (2018). Empowering the Self-Efficacy of Teachers in Malaysia through the Academic Revolution 4.0. International Journal of Academic Research in Business and Social Sciences, 8(11), 894-901.

Copyright: (C) 2018 The Author(s)

Published by Human Resource Management Academic Research Society (www.hrmars.com)

This article is published under the Creative Commons Attribution (CC BY 4.0) license. Anyone may reproduce, distribute, translate and create derivative works of this article (for both commercial and non-commercial purposes), subject to full attribution to the original publication and authors. The full terms of this license may be seen

at: http://creativecommons.org/licences/by/4.0/legalcode

Vol. 8, No. 11, 2018, Pg. 894 - 901

http://hrmars.com/index.php/pages/detail/IJARBSS

JOURNAL HOMEPAGE

Full Terms \& Conditions of access and use can be found at http://hrmars.com/index.php/pages/detail/publication-ethics 


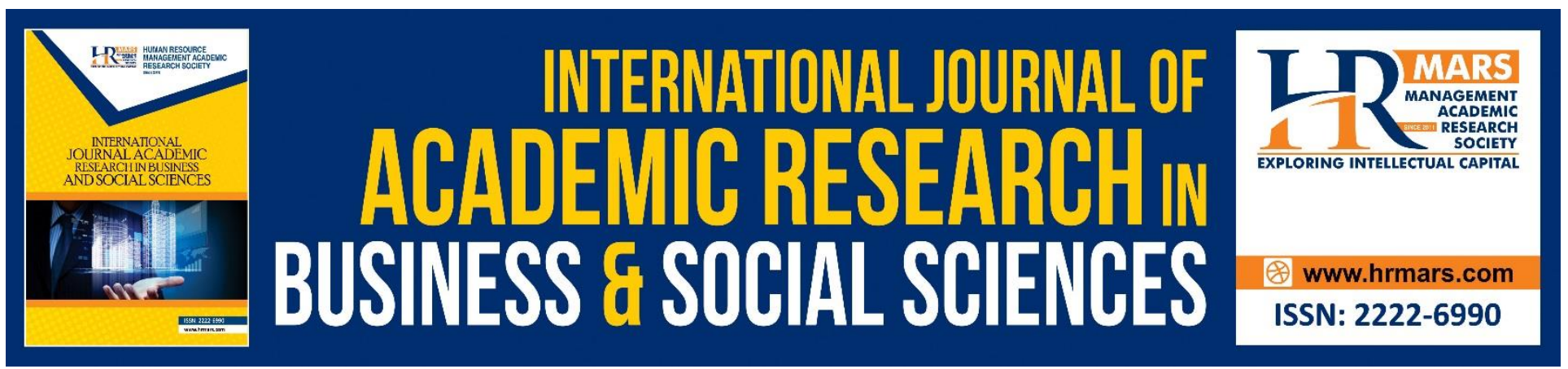

\title{
Empowering the Self-Efficacy of Teachers in Malaysia through the Academic Revolution 4.0
}

\author{
Nor Asmawati Ismail \& Najihah Abd Wahid \\ Universiti Sultan Zainal Abidin \\ Email: asmawati730122@gmail.com
}

\begin{abstract}
One of the vital elements in the dimension of teacher's self-efficacy is the teaching strategy in classrooms. However, the Malaysia Education Blueprint (2013-2025) reported that the high standard of teaching by opting many of the best practices of pedagogy only totalled $12 \%$, meanwhile $38 \%$ still on the satisfaction level. On the other side, 50\% from the research's observation indicated that the delivered teaching considered to be unsatisfied. The teaching becomes dull and unattractive whenever the teachers are depending more on the passive lecture method during delivering the content of the subject. Hence, through the content analysis, this research was trying to examine the current teaching's design that can be applied by teachers during teaching and facilitating. This research paper indicates the findings that the high-efficacy of teachers need to become skilled at the field of information technology since the current students of $Z$ and Alpha generation are preferring to follow the learning session that is assisted by the modern telecommunication tools. The findings also summarizing that the teachers need to have a paradigm shift in the process of delivering the knowledge, hence the teachers and students are not lagging behind the stream of revolution 4.0 and the demands of education in this 21st century.
\end{abstract}

Keywords: Self-Efficacy Of Teachers, Academic Revolution 4.0

\section{Introduction}

The advancement of the education system in a country depends on the quality and skills of a teacher. Teachers or educators are regarded as one of the important assets that able to produce the wholesome and first-class mentality human capital.

One of many ways to actualize the aim of Malaysia Ministry of Education towards producing the quality teachers is through the empowerment of self-efficacy. The self-efficacy is scientifically referring to what possible extent that an individual chooses to be certain towards own capability in order to achieve certain targets. It is an assessment of the ability to organize and completing the sequences of needed action performance in acquiring the targeted aim (Bandura, 1982). 
INTERNATIONAL JOURNAL OF ACADEMIC RESEARCH IN BUSINESS AND SOCIAL SCIENCES Vol. 8, No. 11, Nov, 2018, E-ISSN: 2222-6990 @ 2018 HRMARS

Meanwhile, the teacher's self-efficacy is the trust that is formed related to the ability of a teacher in influencing the student, including amongst the less-motivated and problematic ones to study and attain the excellent achievement. The study conducted by Dibapile (2012) able to prove that the selfefficacy of teachers is the important catalysing factors towards the excellence of students.

Tschannen-Moran and Hoy (2001) defined the teacher's self-efficacy as a certainty that is possessed by a teacher towards his or her capability in teaching and motivating the students without considering their competence and family background.

There are three factors proposed by Tschannen-Moran and Hoy (2001) in explaining the teacher's self-efficacy; efficacy on the teaching strategy, efficacy on the classroom management and efficacy on the student's involvement. Nonetheless, this research paper will be only focussing on teacher's self-efficacy on teaching strategy by attaching the elements based on the industrial revolution 4.0.

\section{Education of the Era Revolution 4.0}

According to the generation theory, there are five generations that are dominating the current world; Baby Boomers, $\mathrm{X}$ generation, $\mathrm{Y}$ generation, Z generation and Alpha generation (Codrington \& GrantMarshall, 2013). The Baby Boomers were born during the period of 1946 until 1964, aged between 54 until 72 years old (Lyons, S. T., Schweitzer, L., \& Ng, E. S., 2015). In this sense, the educators that are coming from this group were having pension from their services since the compulsory retirement age amongst the public servants is at the age of 60 (Pekeliling Jabatan Perkhidmatan Awam, 2011) or if any of them still on their duty, they just need to wait for a few years more to retire. Followed by the $X$ generation that was born between 1965 until 1980, and currently at the age of 38 to 53 years old. In putting this generation into the shoes of a teacher, this generation already being in service around 15 to 30 years old, which considered as a mature period for any teachers in delivering the knowledge towards their students. Meanwhile, Y generation was born on 1981 until 1994 and they are calculated between the range of 24 to 37 years old. This generation started to know and apply the technology tools in education, widely.

Meanwhile, the Z generation was born between 1995 until 2010 and also known as I-Generation, Net Generation or Internet Generation. Logically, they were giving birth by the $X$ and $Y$ generation. Rothman, D (2016) identified that the $Z$ generation is a group of people that is too excessive in utilizing the technology but they are lacking in communication skill. They are multi-tasking, moving faster and able to create and produce more products compared to previous generations (Sharil, Nazuha \& Suaiman, 2017).

The alpha generation is the youngest group that are exposed and introduced to telecommunication tools, since their early childhood. This generation is generally at the age of seven years old and below, born from 2011 until 2025. The alpha members are living in the cyberspace, and their interest in the field of modern telecommunication is developed within themselves as early as one year old. 
This situation is a challenge for teachers since the alpha generation will taking their place in the education world with the attachment of a sophisticated paradigm shift. Henceforth, teachers need to equip themselves by being pro-active towards handling the current demand of the education world, especially in the strategy aspect of teaching and facilitating. The skills and expertise of teachers in the field of ICT enable the transmission process can be transformed in a better and effective way. This is supported by the research done by Rafiza and Maryam (2017) that identified the medium of teaching based on multimedia able to create an effective learning session.

\section{Teacher's self-efficacy towards teachings strategy based on the industry revolution $\mathbf{4 . 0}$}

Teaching strategy refers to the ways of how teachers are handling and monitoring the process of teaching and learning. It relates to the ability of the teachers to use the numerous of teaching strategy whenever they are encountering the different achievement and acceptance rate of students towards the learning process. Self-efficacy of teachers also explaining the confidence level of teachers towards the different levels of questions that being raised by their students.

In brief, the teacher's self-efficacy is referring to the assurance of a teacher that is relating to the selfability to arrange and perform the required series of actions in order to complete their teaching's responsibility. It is also relating to the teachers' confidence towards the knowledge, skills and the possessed ability in a way of achieving certain aims.

In this globalization era, teachers need to conduct self-introspection regarding the skills and their ability in the field of information technology. This statement is seconded for the situation that requires a teacher that is working in the digital epoch need to encounter the students that belong to $Z$ and Alpha generations. These two groups are seeming to be very skilful and interested in the countless gadget function and current telecommunication tools (Shatto \& Erwin, 2016).

There are multiple teaching strategies and facilities that can be applied by teachers during handling the students from the $Z$ and alpha generations. Amongst of the ways are heutagogy, paragogy and cybergogy. Heutagogy requires creative and innovative thinking amongst teachers and students during the teaching and learning process. It implements the holistic approach (Blaschke and Hase, 2016) to develop the ability and capability of students. The students possess autonomy and become the major agent in their own learning experience.

The method of gamification is also said to have its own ability to attract the $Z$ and alpha generation to put their focus constantly during the process of delivering and receiving information (Ding, Guan, and $\mathrm{Yu}, 2017)$. Meanwhile, the research conducted by Siti Norhaida (2017) found that the gamification approach did increase the score achievement of Algebra Expression. According to Dicheva, Dichev, and Angelova (2015), students are feeling bored if the teachers are using the traditional approach during the learning and teaching session. However, they are more interested to learn if the teachers change the method into the gamification approach. This stated approach is not only strengthening their understanding, but they also can learn other skills, such as problem-solving, cooperation between team members and communication. 
INTERNATIONAL JOURNAL OF ACADEMIC RESEARCH IN BUSINESS AND SOCIAL SCIENCES Vol. 8, No. 11, Nov, 2018, E-ISSN: 2222-6990 @ 2018 HRMARS

Teaching Strategy of Reciting Quran by Talaqi Musyafahah Through the Method of Online Learning Talaqi musyafahah is the oldest method along the history of Quranic teaching, which was the technique practised by Jibril AS towards Prophet Muhammad PBUH (Rashidah, Rosila \& Jaafar, 2016). Jibril AS recited the Quranic verses, and Muhammad PBUH copied the way of how they are being recited while Jibril monitored the recitation. Afterwards, Rasulullah PBUH memorized those verses and passed the recitation to his sahabah (companions). As how practised by Muhammad PBUH, the sahabah also copied the recitation from what they heard.

The word talaqi derived from the Arabic words of talaqqa-yatalaqqa-talaqqiyan (al-Marbawi, 1990). It brings few meanings; talaqqa as-syai'a means encountering it, talaqqa fulanan means he encounters that person, talaqqa as-syai'a minhu means to take or accept from him, and talaqqa alilma min fulanin means acquiring the knowledge from that person.

Musyafahah from the linguistic perspective means a conversation between two parties (Kamus Idris al-Marbawi, 1990) or a pronunciation from mouth to mouth that is taken from the movements of two lips. It also brings the meaning of showing mutual conversations in the situation of facing to each other (Mu'jam al-Arab al-asasi, n.d.).

In the terminological discussion, talaqi means a direct meeting between teacher and students. Meanwhile, musyafahah means the students acquire the lessons by the means of pronunciation from observing the teachers' lips movement and verbalizing it. Based on these two terminological definitions, it can be understood that the meaning of talaqi and musyafahah is a situation where the students take the way of reciting from respective teachers by carefully listening and observing the mouth movement of their teachers. Afterwards, the students will pronounce and keep repeating the recitation until receive satisfaction that the recitation and pronunciation are correctly uttered. In another word, teachers and students need to be in the same place and at the same place during the learning session of reciting Quran by the methods of talaqi and musyafahah.

However, by the advancement of the current technology able to allow the method of talaqi and musyafahah to be conducted though the teachers and students are separated away in different places. This is due to the learning session is no longer restricted to be conducted face-to-face but able to be organised anytime and anywhere. This approach is called as online learning which only requires teachers and students to meet each other in the cyber world through the applications of Skype, Face Time, Hang Out and WhatsApp video call.

\section{Teacher Challenges in Education Process}

Successes and failures amongst the students always being connected to the accomplishment and flaws of teachers in delivering knowledge towards their students. Nonetheless, the reality of the education process is not only attached to school solely, but the society is also continuously putting their high hopes on the teachers' shoulders towards bringing forth the educated and virtuous generation. 
INTERNATIONAL JOURNAL OF ACADEMIC RESEARCH IN BUSINESS AND SOCIAL SCIENCES Vol. 8, No. 11, Nov, 2018, E-ISSN: 2222-6990 @ 2018 HRMARS

Schedule 1 indicates that the total of pre-school students was 201,249 and they were being under the responsibility of 9,083 of teachers. Meanwhile, the whole total of students and primary school teacher (students=2,099,033; teacher=239,353) and secondary school (students=2,099,033; teachers $=183,153)$. This statistic indicates that the ratio between a pre-school teacher and students is $1: 22$, meanwhile both primary and secondary schools show approximately the same ratio which is 1:11 respectively.

Table 1: Enrolment of students and teachers at pre-school, primary school and secondary school (2017)

\begin{tabular}{|l|l|l|l|l|l|l|}
\hline \multirow{2}{*}{ Level } & \multicolumn{3}{|c|}{ Enrolment } & \multicolumn{3}{c|}{ Teachers } \\
\cline { 2 - 7 } & \multicolumn{1}{|c|}{ Male } & \multicolumn{1}{c|}{ Female } & \multicolumn{1}{c|}{ Total } & \multicolumn{1}{c|}{ Male } & Female & \multicolumn{1}{c|}{ Total } \\
\hline Pre-school* & 101,355 & 99,894 & 201,249 & 1,070 & 8,171 & 9,083 \\
\hline $\begin{array}{l}\text { Primary } \\
\text { School** }\end{array}$ & $1,371,644$ & $1,302,318$ & $\begin{array}{l}2,673,96 \\
2\end{array}$ & 71,349 & $\begin{array}{l}168,00 \\
4\end{array}$ & $\begin{array}{l}239,35 \\
3\end{array}$ \\
\hline $\begin{array}{l}\text { Secondary } \\
\text { School** }\end{array}$ & $1,042,207$ & $1,056,826$ & $\begin{array}{l}2,099,03 \\
3\end{array}$ & 54,454 & $\begin{array}{l}128,69 \\
8\end{array}$ & $\begin{array}{l}183,15 \\
2\end{array}$ \\
\hline Total & $2,413,851$ & $2,359,144$ & $\begin{array}{l}4,772,99 \\
5\end{array}$ & $\begin{array}{l}125,80 \\
3\end{array}$ & $\begin{array}{l}296,70 \\
2\end{array}$ & $\begin{array}{l}422,50 \\
5\end{array}$ \\
\hline
\end{tabular}

Notes:

1. The stated data only involves the schools under Ministry of Education Malaysia.

2. The whole total is not including pre-school.

3. Data retrieved on 31st January 2017.

* Pre-school National Educational System (SMPK)

** The Student Database Application (APDM)

Source: Ministry of Education Malaysia (2017).

Table 1 also indicates the whole total numbers of students as much as 5,074,612 altogether. This huge enrolment became a challenge for teachers in Malaysia since the current students from those levels of pre-school, primary and secondary are from the $Z$ and Alpha generations that are undoubtedly living in the massiveness of information technology era. Certainly, their tendency and interest to apply the countless of sophisticated tools in daily life, including during the learning process are considerably high. Hence, this is the benchmark of how important the self-efficacy amongst teachers since this kind of educators will take this problem as a challenge and strive to overcome it. Meanwhile, the low self-efficacy teachers will see this tribulation as an obstructing element towards achieving certain accomplishments.

\section{Conclusion}

Nowadays, teachers have to encounter the challenges of technology and the variances of modern technology. Henceforth, a paradigm shift needed to be adopted by them in the process of educating and nurturing the $Z$ and Alpha generation. However, the high self-efficacy teachers always being selfprepared with multiple of knowledge, not only restricted to curriculum and pedagogy but also skills 
INTERNATIONAL JOURNAL OF ACADEMIC RESEARCH IN BUSINESS AND SOCIAL SCIENCES

Vol. 8, No. 11, Nov, 2018, E-ISSN: 2222-6990 @ 2018 HRMARS

related to the application of information technology in order to cope with the current demands. The teachers also should be skilful in optimizing the various kinds of applications from websites as part of strategies to be implemented during the process of learning and facilitating. Through this method, students will not lag behind the progressive education 4.0 and the requirement of education in this 21st era.

\section{ACKNOWLEDGEMENT}

We express our deepest gratitude to the Centre for Research Management, Innovation \& Commercialization (RMIC) UniSZA for sponsoring and supporting this research.

\section{References}

Bandura, A. (1982). Self-Efficacy Mechanism in Human Agency. American Psychologist 37 (2), pp. 122-147

Blaschke, L. M., \& Hase, S. (2016). Heutagogy: a holistic

framework for creating twenty-first-century self-determined learners. In The future of ubiquitous learning (pp. 25-40). Springer, Berlin, Heidelberg.

Dibapile, W. T. S. (2012). A Review of Literature on Teacher Efficacy and Classroom Management. Journal of College Teaching \& Learning, 9(2), 79-92.

Dicheva, D., Dichev, C., Agre, G., \& Angelova, G. (2015). Gamification in education: A systematic mapping study. Journal of Educational Technology \& Society, 18(3).

Ding, D., Guan, C., \& Yu, Y. (2017). Game-Based learning in tertiary education: A new learning experience for the Generation Z. International Journal of Information and Education Technology, 7(2), 148.

Graeme Codrington dan Sue Grant-Marshall. (2013). Mind The Gap: Own Your Past Know Your Generation Choose Your Future. Penguin South Africa; 2nd ed edition.

Jabatan Perkhidmatan Awam. (2011). Pekeliling Perkhidmatan Bilangan 11 Tahun 2011

Kamus al-mu'jam al-a'rabi al-asasi. (n.d.).

Kementerian Pendidikan Malaysia. (2017). Quick Facts. https://moe.gov.my/images/Terbitan/Buku-informasi/QUICK-FACTS-2017/20170809_QUICKFACTS_2017_FINAL5_interactive.pdf

Sharil, M.M.S., Nazuha, N. \& Baharudin, N.S. (2017). Overview of 'Generation Z' Behavioural Characteristic and its Effect Towards Hostel Facility. International Journal of Real Estate Studies, 11 (2).

al-Marbawi, M.I. (1990). Kamus Idris Al-Marbawi ‘Arab Melayu. Kuala Lumpur: Darul Fikir.

Razak, R.A. \& Rahman, M.A. (2017). Pembinaan media pengajaran berasaskan multimedia di kalangan guru ICTL. JuKu: Jurnal Kurikulum \& Pengajaran Asia Pasifik, 1(2), 20-31.

Hasan, R.M., Rosila, N. \& Jaafar, W.A. (2016). Kaedah Pembelajaran Serentak dalam Meningkatkan Pencapaian Kelancaran Bacaan, Fasohah dan Hukum Tajwid Murid Sekolah Rendah. Persidangan Kebangsaan Isu-Isu Pendidikan Islam (ISPEN-i).

Rothman, D. (2016). A Tsunami of learners called Generation Z. URL: http://www. mdle. net/JoumaFA_Tsunami_of_Learners_Called_Generation_Z. pdf. 
INTERNATIONAL JOURNAL OF ACADEMIC RESEARCH IN BUSINESS AND SOCIAL SCIENCES

Vol. 8, No. 11, Nov, 2018, E-ISSN: 2222-6990 @ 2018 HRMARS

Lyons S. T., Schweitzer L., Ng. E.,S.,W. (2015). “How have careers changed? An investigation of changing career patterns across four generations", Journal of Managerial Psychology, Vol. 30 Issue: 1, pp.8-21

Shatto, B., \& Erwin, K,. (2016). Moving on From Millennials: Preparing for Generation Z. The Journal of Continuing Education in Nursing. 47(6):253-254

Rahman, S.N.A. (2017). Pendekatan gamifikasi dalam pengajaran dan pembelajaran terhadap murid tingkatan dua bagi topik ungkapan algebra. Master Thesis. Universiti Tun Hussein Onn Malaysia.

Tschannen-Moran, M., \& Hoy, A. W. (2001). Teacher efficacy: Capturing an elusive construct. Teaching and teacher education, 17(7), 783-805. https://doi.org/10.1016/S0742$\underline{051 \times(01) 00036-1}$ 